\title{
Pathology of Congenital Rubella in Jamaica
}

\author{
MARIGOLD J. THORBURN and COLIN G. MILLER \\ From the Departments of Pathology and Paediatrics, University of the West Indies, Kingston, Jamaica
}

The clinical, virological, and haematological features of the congenital rubella syndrome have been well documented in the recent American paediatric literature, as a result of the epidemic which occurred in 1964. However, apart from isolated case reports (Lambert, Stern, and Wellsteed, 1965; Stern and Williams, 1966; Menser, Dorman, Reye, and Reid, 1966) pathological data have been limited to descriptions of certain organs or tissues as part of larger series of clinical studies (Plotkin, Oski, Hartnett, Hervada, Friedman and Gowing, 1965; Korones, Ainger, Gilles, Roane, Sever, and Fuste, 1965; Cooper, Green, Krugman, Giles, and Mirick, 1965), or to the pathology of abortuses (Töndury and Smith, 1966).

In the early months of 1965 , an epidemic of rubella occurred in Jamaica, possibly as a sequel to that in the United States. As a result of this, many babies born in the University College Hospital of the West Indies (U.C.H.) showed features of congenital rubella. The clinical findings in 20 of these infants have been described in a previous publication (Miller and Thorburn, 1966). In addition to the babies born in U.C.H., many other affected babies have been seen in the out-patient department, and it has been estimated that there are approximately 300 affected babies in the island. It is the purpose of this paper to describe and discuss the pathological findings in 8 infants who came to necropsy.

\section{Materials and Methods}

Of the babies to be described, 4 were included in the clinical series, 1 infant was a stillbirth born in U.C.H., and 3 were born elsewhere, but died in U.C.H. during the same period. All the material, except the gross appearances in 2 cases, was examined by one of us. Paraffin-embedded sections and haematoxylin and eosin stains were used routinely on all tissues.

We have been unable so far, due to lack of suitable tissue culture material, to confirm the diagnosis by virus studies. Because of this, several cases of suspected congenital rubella, which were not quite typical, were excluded from the study.

Received October 10, 1966.

\section{Results}

Clinical findings. The clinical features of 20 cases born at U.C.H. have been fully described in a previous article (Miller and Thorburn, 1966). The clinical features of the 8 cases who came to necropsy are summarized in Table I. The only additional comments necessary are that lymphadenopathy was only recorded in 1 of these 8 , diarrhoea was fairly frequent, occurring in 3 , and teeth were seen at birth in 3. 2 infants (Cases 6 and 7) died on admission and clinical information was scanty.

Pathological findings. These can be divided into 3 groups: (a) normal, (b) abnormal features already well documented, and (c) abnormalities not previously emphasized. All the pathological data are summarized in Table II.

(a) Normal. Most organs showed abnormalities of some degree though these varied in different cases.

Liver: As none of the cases had shown clinical evidence of liver damage, the absence of histological hepatic damage is not surprising. Several cases showed mild degrees of fatty change, a not uncommon finding in our necropsies, and most showed passive congestion, presumably related to congestive failure.

Lymph nodes: Although enlarged in one case, there was no histological abnormality either in peripheral nodes or in the lymphoid tissues of the alimentary tract, apart from a mild hyperplasia.

Other organs showing no significant abnormality were the pancreas, adrenals, and the bowel, though the latter was examined histologically in only 4 instances because of poor preservation.

(b) Abnormal features. All infants showed marked evidence of growth retardation. This was particularly striking in the newborn babies, who were small, thin, wrinkled, wizened little infants, with receding chins. Only one infant was jaundiced, due to Rhesus isoimmunization.

Cardiovascular abnormalities included patent ductus arteriosus in all the infants. This was accompanied by marked cardiomegaly, especially of 
TABLE I

Clinical Features

\begin{tabular}{|c|c|c|c|c|c|c|c|c|c|c|c|}
\hline & & & & \multicolumn{8}{|c|}{ Case No. } \\
\hline & & & & 1 & 2 & 3 & 4 & 5 & 6 & 7 & 8 \\
\hline $\begin{array}{l}\text { Age first seen } \\
\text { Age at death } \\
\text { Dysmaturity } \\
\text { Birthweight (g.) } \\
\text { Gestation (wk.) } \\
\text { History of rubella } \\
\text { Thrombocytopen } \\
\text { Teeth or cysts } \\
\text { Diarrhoea } \\
\text { Congestive failure } \\
\text { Patent ductus } \\
\text { Other defects } \\
\text { ECG changes } \\
\text { Hepatitis .. } \\
\text { Splenomegaly } \\
\text { Cataracts . } \\
\text { Microphthalmia } \\
\text { Microcephaly } \\
\text { Irritability etc. } \\
X \text {-ray bone chang } \\
\text { Comments }\end{array}$ & $\begin{array}{l}\cdots \\
\cdots \\
\cdots \\
\cdots \\
\text { aia } \\
\cdots \\
\therefore \\
\cdots \\
\cdots \\
\cdots \\
\cdots \\
\cdots \\
\cdots \\
\cdots \\
\cdots\end{array}$ & $\begin{array}{l}\cdots \\
\cdots \\
\cdots \\
\cdots \\
\cdots \\
\cdots \\
\cdots \\
\cdots \\
\cdots \\
\cdots \\
\cdots \\
\cdots \\
\cdots \\
\cdots \\
\cdots\end{array}$ & 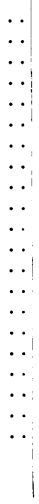 & $\begin{array}{c}\text { Birth } \\
4 \text { dy. } \\
+ \\
1910 \\
40 \\
+ \\
+ \\
+ \\
+ \\
+ \\
+ \\
\bar{?} \\
- \\
+ \\
+ \\
- \\
- \\
- \\
+ \\
\text { Rh iso- } \\
\text { immuniza- } \\
\text { tion }\end{array}$ & $\begin{array}{c}\text { Birth } \\
15 \text { wk. } \\
\pm \\
2200 \\
38 \\
- \\
- \\
- \\
+ \\
+ \\
+ \\
+ \\
+ \\
+ \\
- \\
- \\
+ \\
+ \\
-\end{array}$ & $\begin{array}{c}\text { Birth } \\
15 \frac{1}{2} \text { wk. } \\
+ \\
2160 \\
41 \\
+ \\
+ \\
+ \\
+ \\
+ \\
+ \\
+ \\
+ \\
+ \\
- \\
+ \\
+ \\
+ \\
+ \\
?\end{array}$ & $\begin{array}{c}\text { Birth } \\
7 \frac{1}{2} \text { mth. } \\
+ \\
1700 \\
34 \\
- \\
+ \\
+ \\
+ \\
+ \\
+ \\
- \\
+ \\
- \\
+ \\
- \\
- \\
+ \\
+ \\
+ \\
\text { Ductus } \\
\text { tied }\end{array}$ & $\begin{array}{c}\text { Birth } \\
\text { Stillborn } \\
+ \\
2100 \\
42 \\
? \\
- \\
- \\
- \\
- \\
- \\
- \\
- \\
- \\
+ \\
- \\
- \\
- \\
- \\
\text { Stillbirth }\end{array}$ & $\begin{array}{c}3 \text { wk. } \\
3 \text { wk. } \\
+ \\
? \\
? \\
? \\
? \\
\bar{?} \\
+ \\
+ \\
? \\
? \\
+ \\
+ \\
+ \\
- \\
- \\
? \\
? \\
\text { No } \\
\text { history }\end{array}$ & $\begin{array}{c}4 \text { mth. } \\
4 \text { mth. } \\
+ \\
? \\
? \\
? \\
? \\
\bar{?} \\
+ \\
+ \\
? \\
? \\
- \\
+ \\
+ \\
\overline{+} \\
+ \\
? \\
\text { No } \\
\text { history }\end{array}$ & $\begin{array}{c}5 \text { wk. } \\
9 \text { wk. } \\
+ \\
2150 \\
40 \\
- \\
- \\
+ \\
+ \\
+ \\
+ \\
+ \\
+ \\
- \\
- \\
- \\
+ \\
+ \\
+ \\
\text { Haemolysis }\end{array}$ \\
\hline
\end{tabular}

the right ventricle, in all except 2 . These were the stillborn infant (Case 5), and another infant (Case 4), who had had the ductus ligated at 3 months of age. Other cardiac anomalies were seen in Case 3 only: this child had a coarctation of the aorta and possibly stenosis of the right upper lobe pulmonary artery. Histologically, the myocardial degeneration described by Korones et al. (1965) was not seen in any case, in spite of the electrocardiographic changes suggestive of myocardial damage. In 2 cases there was very mild vacuolation of the cardiac muscle. In 2 there was quite a marked degree of myocardial fibrosis, and in 1 there was a large single focus of inflammation, subpericardial in situation, and consisting mainly of round cells.

Pneumonitis was seen in all the liveborn infants in varying degrees of severity, ranging from a few patchy areas in Case 7 to the most extensive involvement in Case 4, the oldest. There was no evidence of permanent lung damage in the form of

TABLE II

Summary of Pathological Features

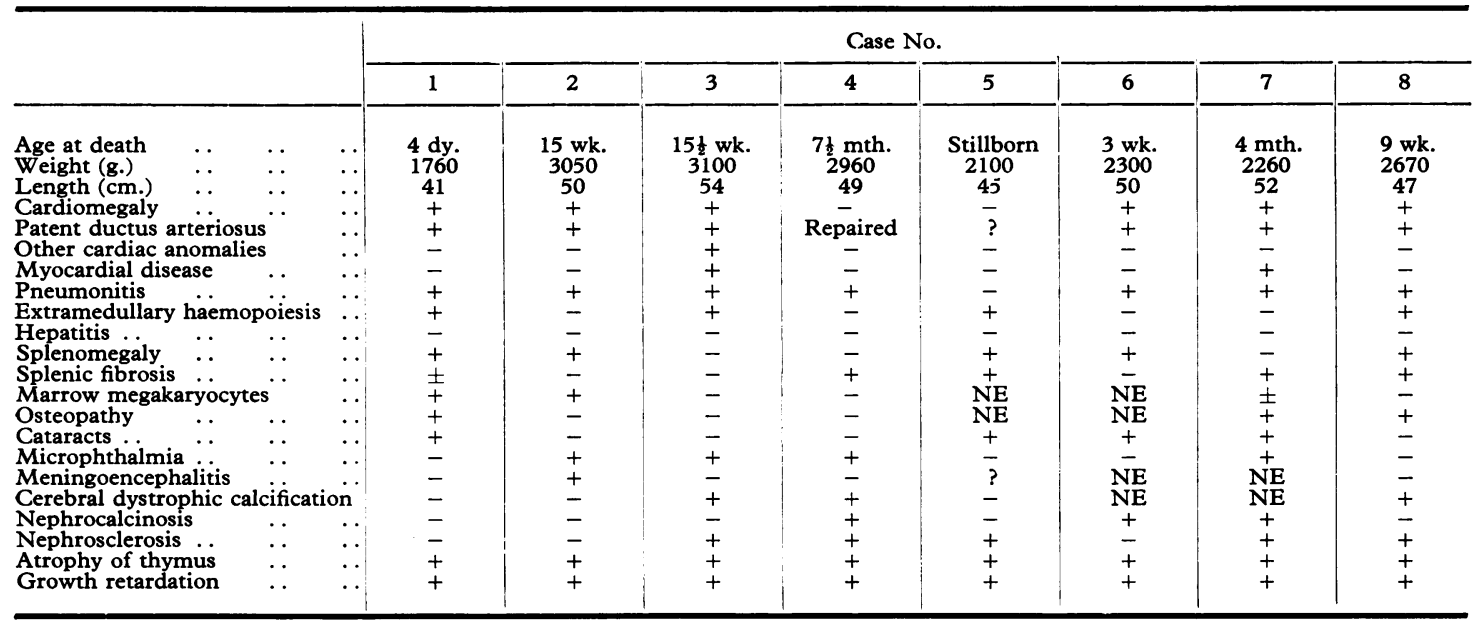

$\mathrm{NE}=$ not examined. 


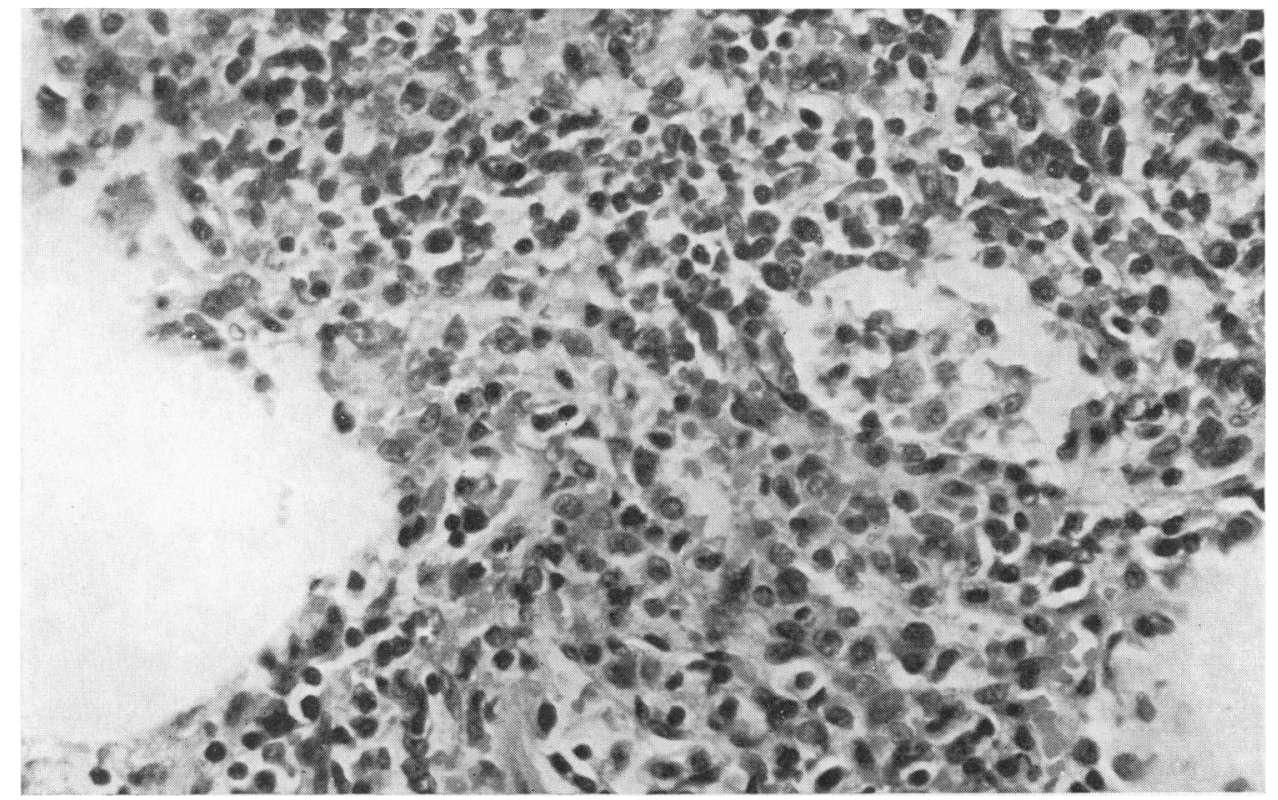

FIG. 1.-Interstitial pneumonitis with lymphocytic infiltration of septa and accumulations of macrophages in air-spaces. (H. and $E$. $\times 145$.)

fibrosis in any case. In 4 children it was complicated by a more acute bronchopneumonia, in 1 (Case 7) by patchy haemorrhage, and in another (Case 1) by hyaline membrane disease and inhalation of squames. In all of them it was quite characteristic in appearance, there being extensive lymphocytic infiltration of the interstitial tissues and large numbers of eosinophilic macrophage-like cells in the air-spaces (Fig. 1). In 2 there were marked accumulations of lymphocytic cells around blood vessels.

Splenomegaly was seen in 5 cases and fibrosis in 5. However, fibrosis was most pronounced in the smaller spleens, except in Case 3. There was some relation to age, as the younger babies had larger spleens though the stillborn infant had quite marked, though diffuse fibrosis. Fibrosis was most striking in Case 7 (Fig. 2), where the spleen was less than the expected weight for the age. Congestion was a prominent feature in the larger spleens, suggesting that as this lessens, fibrosis increases and contraction ensues. In Cases 1 and 8 fibrosis was more diffuse and difficult to demonstrate without the use of special stains. With increasing fibrosis there was atrophy and diminution in number of the follicles.

The features of rubella osteopathy have been well described (Rudolph, Singleton, Rosenberg, Singer, and Phillips, 1965) and need no further comment here other than that they were seen in 3 cases. The diminution of megakaryocytes in the marrow, the presence of extramedullary haematopoiesis, cataracts, and microphthalmia are all well documented.

The brain was not grossly abnormal in any case apart from severe congestion in Cases 1 and 5 . Focal meningoencephalitis (Fig. 3) was seen in Case 2, consisting mainly of a patchy round cell infiltration of the meninges and occasional focal accumulations in the cortex. There was also a suggestion of lymphocytic infiltration in Case 5, but it was difficult to distinguish this from the appearances often seen in the newborn.

(c) New abnormalities. These were seen in the brain, kidneys, and thymus.

In 3 out of 6 infants whose brains were examined, dystrophic calcification was seen in relation to blood vessels (Fig. 4). This is perhaps not a surprising finding, as one might expect it to be a sequel of prenatal infection, as in congenital syphilis or toxoplasmosis. All the affected infants were microcephalic.

Renal lesions of two types were seen. Nephrocalcinosis was seen in 3 cases, in the cortex only. It is our impression that this is not a common feature of necropsies in infants in this department. A study of the incidence and associations of nephrocalcinosis 


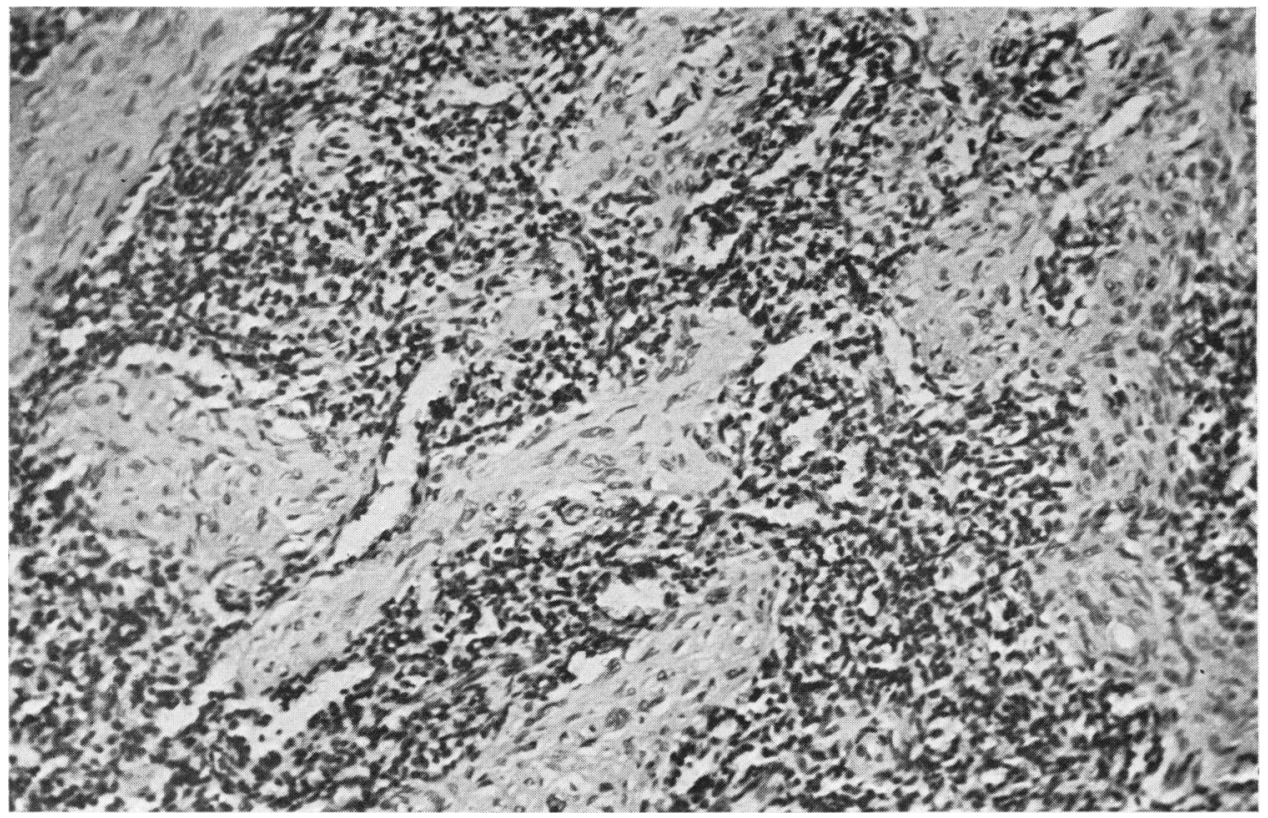

Fig. 2.-Fibrosis of the spleen in Case 7. (H. and E. $\times$ 145.)

in our necropsies is now in progress. The other of glomerulosclerosis in 5. At first this was thought $\cap \vec{\bullet}$ feature, which had previously been noted by Swan to be the usual type of so-called 'congenital 0 공 (1944) in 2 out of 3 cases of rubella, was the presence glomerulosclerosis', well described by Friedman,

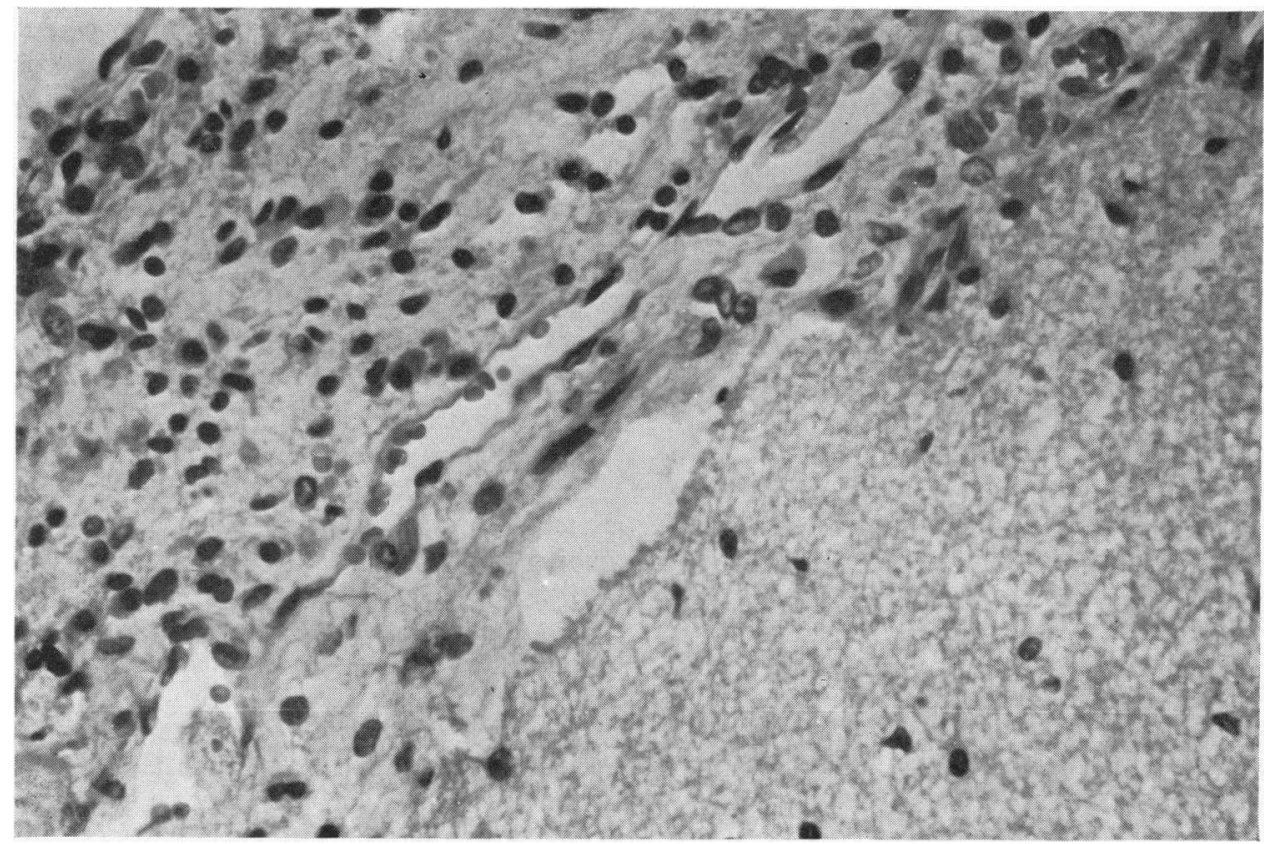

FIG. 3.-Focal meningitis in Case 2. (H. and E. $\times 155$. 


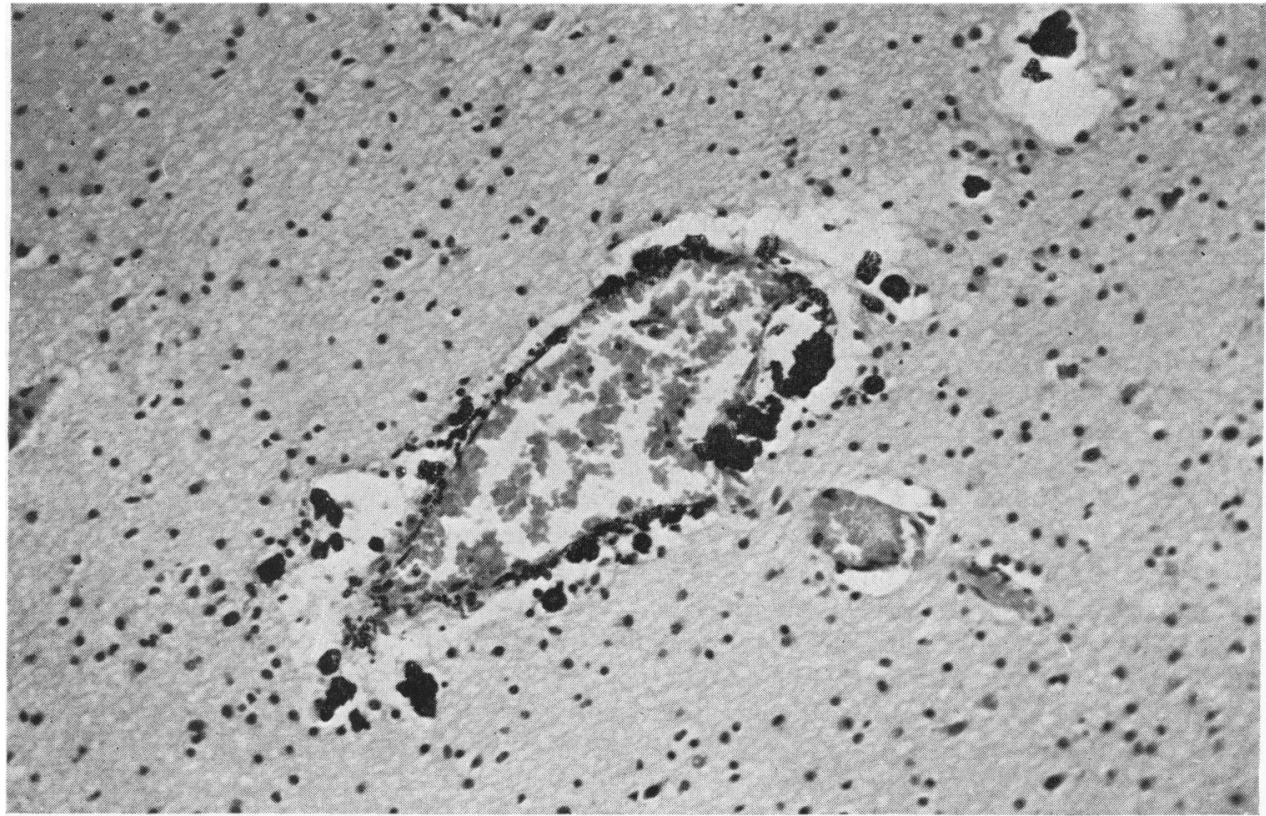

FIG. 4.-Dystrophic calcification in Case 4. (H. and E. $\times$ 160.)

Grayzel, and Lederer (1942) and extensively investigated by Emery and Macdonald (1960). The latter suggested that in the cases where the glomeruli

were more peripherally situated, the condition might be related to late intrauterine or early postnatal infection. In our cases, all the lesions were in a

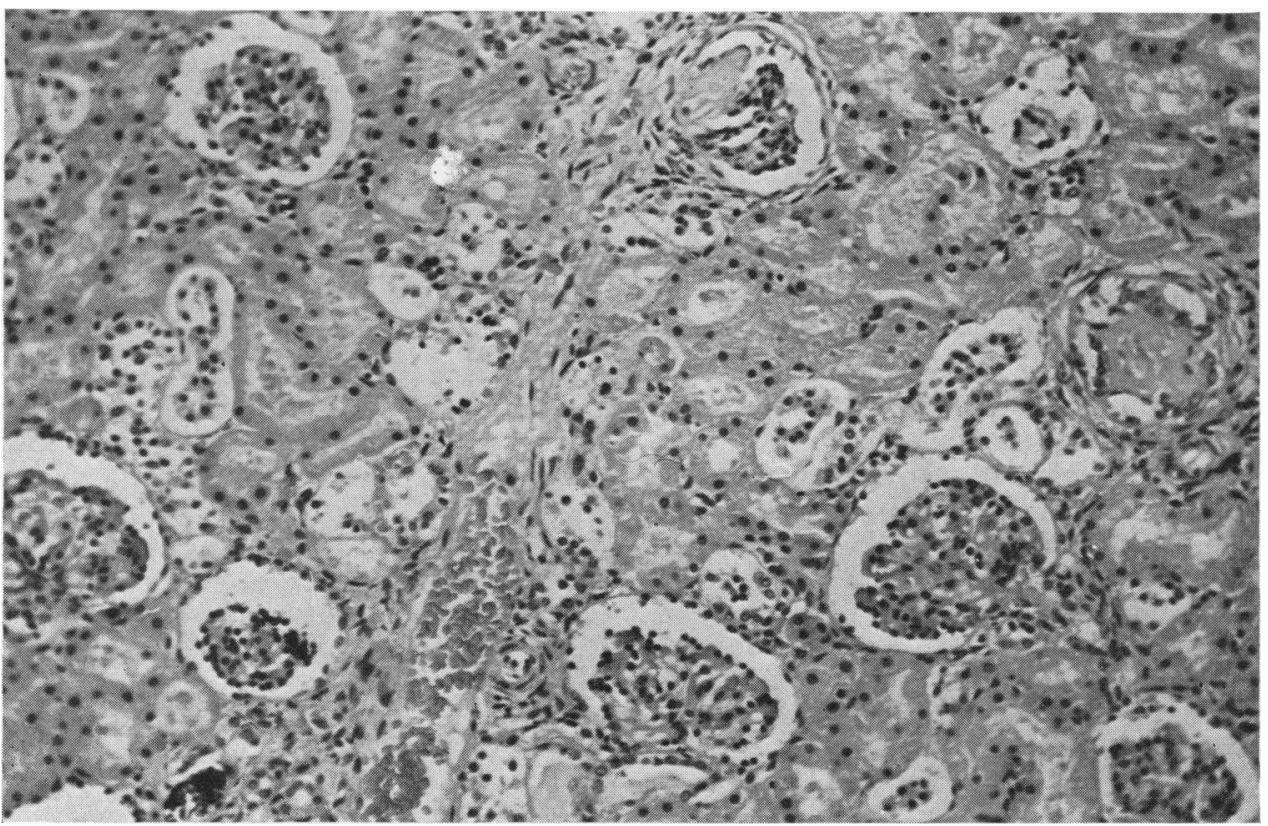

FIG. 5.-Nephrosclerosis and nephrocalcinosis in Case 4. (H. and E. $\times 160$. 
peripheral position. There appeared to be no connexion between the presence of the two lesions, though they occurred simultaneously in 2 (Cases 4 (Fig. 5) and 7). There was also no relation to age or to the presence of dystrophic calcification in the brain. As in previous reports there were no detected abnormalities of renal function, and there were no active lesions or inflammation.

The final feature, which is again perhaps not surprising, was the small size of the thymus. In all the cases, the thymus weighed considerably less than the expected weight both for the age and size of the infant, in 2 infants being extremely shrunken. Histologically, one showed fibrosis with calcification, the others appeared normal.

\section{Discussion}

The clinical features and the diverse manifestations now known to be part of the rubella syndrome have been discussed in our previous paper. The discussion here will be mainly concerned with the pathological features and their possible significance with regard to the aetiology and nature of the disease.

Our findings on the whole are similar to those previously reported, with the exception of the absence of severe myocardial damage as described by Korones et al. (1965), and hepatic damage. In addition, we have found a significant number of cases showing calcification in the kidneys and brain and in one case in the thymus, and nephrosclerosis. The significance of the latter is debatable, as Friedman et al. (1942) found it in $17 \%$ of newborn infants, and Emery and Macdonald (1960) found it in 10 to $70 \%$ of infants up to 1 year of age. However, its occurrence in 5 out of 8 infants seems more than a chance association. It may represent burnt-out inflammation, as does the calcification.

Other authors have also not commented on the small size of the thymus, though the size of this organ is such a variable feature, especially in the presence of a prolonged infection, that, again, the significance of this finding is not obvious.

It is now well recognized that congenital rubella is a chronic infection of a most unusual type, in that virus persists in many tissues throughout intrauterine life and several months into postnatal life (Alford, Neva, and Weller, 1964). In spite of this, there are high antibody levels in the blood (Plotkin, Dudgeon, and Ramsay, 1963). In addition, there is evidence of immunological disturbance, as shown in levels of IgM and IgG (Bellanti, Artenstein, Olson, Buescher, Luhrs, and Milstead, 1965; Soothill, Hayes, and Dudgeon, 1966). These facts, combined with a picture of antenatal and postnatal growth retardation, thrombocytopenia, susceptibility to infections, especially pneumonia and diarrhoea, lymphoid hyperplasia, splenic enlargement and later atrophy, liver, myocardial, renal, and brain damage, and thymic atrophy suggest two possibilities. First, the syndrome could be due entirely to virus multiplication inhibiting cell mitosis. This could account for the pathological lesions that develop initially, the effects of which in turn would inhibit normal growth. The prevention of growth of tissue cultures is evidence of intracellular multiplication of virus. However, though affected infants continue to harbour rubella virus in many tissues after birth, the majority stop excreting virus after about 6 months, and we have clinical evidence that growth retardation persists after this time, up to 18 months in the oldest of our cases. The second possibility is that the rubella syndrome is a runting disease (allogenic disease, graft versus host reaction) of laboratory animals. Scott (1966) has suggested that some forms of intrauterine growth retardation may have an immunological aetiology, and quotes Elliott (1964) as suggesting that the term 'runt syndrome' be used for such cases.

There are several aspects to this hypothesis. First, runt disease is usually produced by injection of immunologically competent cells into a host which is unable to reject them, (i) because it is immunologically immature at the time of injection, or (ii) because the host contains all the antigens present in the graft and therefore regards the graft as self, or (iii) the graft is so large that it overwhelms the immunological defences of the host (Nisbet and Heslop, 1962). The first situation seems more likely in the case of rubella, as the effects are most severe when infection occurs in the first trimester when immunological competence is probably developing. The 'graft' could be a materno-foetal transfusion of lymphocytes which are able to cross the placental barrier, possibly as a direct result of viral damage to the placenta itself. Such damage has been domonstrated in the chorion in 8 out of 12 abortuses examined by Töndury and Smith (1966) from cases of therapeutic abortion for rubella. In one case, they were able to demonstrate the presence of emboli of what appeared to be chorionic cell detritus in the umbilical vein and an arteriole of the brain. Human chimeras have been described by Taylor and Polani (1965) and Kadowaki, Thompson, Zuelzer, Woolley, Brough, and Gruber (1965), in which materno-foetal transfusions of lymphocytes were postulated because of the presence of XX cell lines in the blood and thymus only, in what appeared to be phenotypic males with a majority of XY cells. In the former case, spontaneous abortion occurred, 
but in the second case, a severe immunological disease developed which was fatal at 16 months. The immunoglobulins at 1 year of age were of a similar order to those found by Soothill et al. (1966) in 4 of their cases of rubella; that is, low IgG level and raised IgM. However, the loss of lymphoid tissue in this case was much more striking, especially in the thymus and alimentary tract, than in our cases of congenital rubella. Further, in no case of rubella so far, has evidence of chimerism or any other chromosomal anomaly been detected (Mellman, Plotkin, Moorhead, and Hartnett, 1965). Evidence in support of this hypothesis would be the finding of negative lymphocyte transfer tests (Gray and Russell, 1963) or tolerance of maternal skin grafts. In addition, it is possible that the case of Kadowaki et al. (1965) was due to situation (iii) of Nisbet and Heslop (1962). A second alternative, and the borderline between this and the first hypothesis is indistinct, is that the runting disease is due to the virus itself. Walters, Joske, Leak, and Stanley (1963), Stanley, Leak, Walters, and Joske (1964), and Walters, Leak, Joske, Stanley, and Perret (1965), in a series of experiments on $\mathrm{PH}$ mice with reovirus types I, II, and III, have produced a condition with acute and chronic phases, which is very similar to runting. Mice surviving the acute phase develop a chronic immunological disease which continues after excretion of the virus stops. The clinical and pathological features vary somewhat in the different types of virus. If this is the situation in rubella, infants who do not appear runted or who survive the runting stage have presumably overcome the autoimmune process and show pathological evidence of burnt-out disease only, e.g. cerebral dystrophic calcification, glomerulosclerosis, etc.

The third aspect is that, if congenital rubella is a runting disease, either of the first or second type, the logical extension of the theory would be the remote possibility of development of lymphomas or Hodgkin's disease. Schwartz and Beldotti (1965) have deomonstrated this transition in the usual type of allogenic disease in F1 hybrid mice, and in fact, Kadowaki et al. (1965) found very suggestive cytogenetic evidence of the development of a preleukaemic state in their case. Stanley and Walters (1966) used their finding that spleen cells from PH mice with reovirus-induced runt disease injected into newborn mice produced in some a lymphoma, as a basis for their hypothesis of a virus aetiology of auto-immune disease and neoplasia, and a reovirus Type III as a cause of Burkitt's lymphoma (Stanley, 1966). If there had been a connexion in the past between rubella and the development of lymphomas, it would surely have been noticed by now, but there is much speculation at present as to whether the strain of rubella virus causing the recent epidemics is the same one as had been involved in the past (J. Pediat., 1965).

\section{Summary}

The pathological features of 8 cases of congenital rubella, resulting from a recent epidemic in Jamaica, have been described. In addition to the findings reported in the recent American paediatric literature, we have found nephrocalcinosis, congenital glomerulosclerosis, cerebral dystrophic calcification, and atrophy of the thymus. A parallel has been suggested between the congenital rubella syndrome and runt disease.

We are grateful to our colleagues in the Department of Pathology for their assistance in performing some of the necropsies, and for allowing us to use their material.

\section{REFERENCES}

Alford, C. A., Jr., Neva, F. A., and Weller, T. H. (1964). Virologic and serologic studies on human products of conception after maternal rubella. New Engl. F. Med., 271, 1275.

Bellanti, J. A., Artenstein, M. S., Olson, L. C., Buescher, E. L., Luhrs, C. E., and Milstead, K. L. (1965). Congenital rubella: clinicopathologic, virologic, and immunologic studies. Amer. F. Dis. Child., 110, 464.

Cooper, L. Z., Green, R. H., Krugman, S., Giles, J. P., and Mirick, G. S. (1965). Neonatal thrombocytopenic purpura and other manifestations of rubella contracted in utero. ibid., 110, 416.

Elliott, P. M. (1964). Quoted by Scott (1966).

Emery, J. L., and Macdonald, M. S. (1960). Involuting and scarred glomeruli in the kidneys of infants. Amer. F. Path., 36, 713.

Friedman, H. H., Grayzel, D. M., and Lederer, M. (1942). Kidney lesions in stillborn and newborn infants. 'Congenital glomerulosclerosis.' ibid., 18, 699.

Gray, J. G., and Russell, P. S. (1963). Donor selection in human organ transplantation. A possible screening test. Lancet, 2, 863.

f. Pediat. (1965). Editorial. Rubella-new light on an old disease. 67, 159.

Kadowaki, J.-I., Thompson, R. I., Zuelzer, W. W., Woolley, P. V., Brough, A. J., and Gruber, D. (1965). XX/XY lymphoid chimaerism in congenital immunological deficiency syndrome with thymic alymphoplasia. Lancet, 2, 1152.

Korones, S. B., Ainger, L. E., Gilles, R. G. M., Roane, J., Sever, J. L., and Fuste, F. (1965). Congenital rubella syndrome: new clinical aspects with recovery of virus from affected infants. f. Pediat., 67, 166.

Lambert, H. P., Stern, H., and Wellsteed, A. J. (1965). Congenital rubella syndrome. Lancet, $2,826$.

Mellman, W. J., Plotkin, S. A., Moorhead, P. S., and Hartnett, E. M. (1965). Rubella infection of human leukocytes. Amer. f. Dis. Child., 110, 473.

Menser, M., Dorman, D. C., Reye, R. D. K., and Reid, R. R. (1966). Renal-artery stenosis in the rubella syndrome. Lancet, 1, 790.

Miller, C. G., and Thorburn, M. J. (1966). An outbreak of congenital rubella in Jamaica. W. Indian med. $\mathcal{F} ., 15,177$.

Nisbet, N. W., and Heslop, B. F. (1962). Runt disease. Brit. med. f., 1, 129.

Plotkin, S. A., Dudgeon, J. A., and Ramsay, A. M. (1963). Laboratory studies on rubella and the rubella syndrome. ibid., 2, 1296. -, Oski, F. A., Hartnett, F. M., Hervada, A. R., Friedman, S., 
and Gowing, J. (1965). Some recently recognized manifestations of the rubella syndrome. F. Pediat., $67,182$.

Rudolph, A. J., Singleton, E. B., Rosenberg, H. S., Singer, D. B., and Phillips, C. A. (1965). Osseous manifestations of the congenital rubella syndrome. Amer. F. Dis. Child., 110, 428.

Schwartz, R. S., and Beldotti, L. (1965). Malignant lymphomas following allogenic disease: transition from an immunological to a neoplastic disorder. Science, 149, 1511 .

Scott, J. S. (1966). Immunological diseases and pregnancy. Brit. med. F., 1, 1559.

Soothill, J. F., Hayes, K., and Dudgeon, J. A. (1966). The immunoglobulins in congenital rubella. Lancet, $1,1385$.

Stanley, N. F. (1966). The aetiology and pathogenesis of Burkitt's African lymphoma. ibid., 1, 961.

—, Leak, P. J., Walters, M. N.-I., and Joske, R. A. (1964). Murine infection with reovirus: II. The chronic infection following reovirus Type 3 infection. Brit. F. exp. Path., 45, 142.

—, and Walters, M. N.-I. (1966). Virus induction of autoimmune disease and neoplasia. Lancet, $1,962$.

Stern, H., and Williams, B. M. (1966). Isolation of rubella virus from a case of neonatal giant-cell hepatitis. ibid., 1, 293.

Swan, C. (1944). A study of three infants dying from congenital defects following maternal rubella in the early stages of pregnancy. F. Path. Bact., 56, 289.

Taylor, A. I., and Polani, P. E. (1965). XX/XY mosaicism in man. Lancet, 1, 1226.

Töndury, G., and Smith, D. W. (1966). Fetal rubella pathology. F. Pediat., 68, 867.

Walters, M. N.-I., Joske, R. A., Leak, P. J., and Stanley, N. F. (1963). Murine infection with reovirus: I. The pathology of the acute phase. Brit. F. exp. Path., 44, 427.

—, Leak, P. J., Joske, R. A., Stanley, N. F., and Perret, D. H. (1965). Murine infection with reovirus: III. Pathology of infection with types 1 and 2. ibid. 46, 200.

\section{Addendum}

Since this paper was submitted, we have recognized a further case of congenital rubella, which was born before the other cases already described. This was the first child of a patient aged 18 years and was born spontaneously at 39 weeks after a normal pregnancy. He weighed only $1530 \mathrm{~g}$. ( $3 \mathrm{lb} .6 \mathrm{oz}$.) and rapidly developed pyrexia, purpura, and a palpable spleen. He died at 54 hours of age.

At necropsy he was a thin, anaemic baby with a rather mature appearance. Weight $1565 \mathrm{~g}$., length $45 \mathrm{~cm}$., and head circumference $30 \mathrm{~cm}$. The findings of note were a patent ductus arteriosus, focal myocarditis, congested lungs with one or two foci of pneumonitis, and a spleen twice normal size which showed severe congestion and fibrosis. The kidneys were mature with extensive congenital glomerulosclerosis and a little nephrocalcinosis, a small thymus, and extensive extramedullary haemopoiesis in heart, liver, and kidneys. The brain weighing $300 \mathrm{~g}$., showed focal necrosis, haemorrhages, perivascular cuffing, and scattered dystrophic calcification. The bone taken was from the sternum so it was not possible to assess the presence of osteopathy, but there were diminished numbers of megakaryocytes in the marrow.

This further case shows similar features to those already reported. 